\title{
Factors affecting lecturers' decision to stay or leave academia, Namibia
}

\begin{tabular}{|c|c|}
\hline $\begin{array}{l}\text { Authors: } \\
\text { Wesley R. Piet } \\
\text { Ebben van }\left.\mathrm{Zy}\right|^{2} \\
\text { Petrus } \mathrm{Nel}^{2,3}\end{array}$ & $\mathrm{ers}^{1,2}$ (iD \\
\hline $\begin{array}{l}\text { Affiliations: } \\
{ }^{1} \text { Department } \\
\text { and Social wor } \\
\text { Health Science } \\
\text { Veterinary Me } \\
\text { University of } \\
\text { Windhoek, Na }\end{array}$ & $\begin{array}{l}\text { f Psychology } \\
\text { k, Faculty of } \\
\text { s and } \\
\text { dicine, } \\
\text { Jamibia, } \\
\text { mibia }\end{array}$ \\
\hline $\begin{array}{l}{ }^{2} \text { Department } \\
\text { Psychology, Fa } \\
\text { Economic and } \\
\text { Sciences, Univ } \\
\text { Free State, Blo } \\
\text { South Africa }\end{array}$ & $\begin{array}{l}\text { f Industrial } \\
\text { culty of } \\
\text { Management } \\
\text { ersity of the } \\
\text { emfontein, }\end{array}$ \\
\hline $\begin{array}{l}{ }^{3} \text { Department } \\
\text { Psychology an } \\
\text { Management, } \\
\text { Johannesburg } \\
\text { South Africa }\end{array}$ & $\begin{array}{l}\text { f Industrial } \\
\text { d People } \\
\text { University of } \\
\text { Johannesburg, }\end{array}$ \\
\hline $\begin{array}{l}\text { Correspondin } \\
\text { Wesley Pieters } \\
\text { wpieters@una }\end{array}$ & g author: \\
\hline $\begin{array}{l}\text { Dates: } \\
\text { Received: } 02 \mathrm{~J} \\
\text { Accepted: } 18 \mathrm{~J} \\
\text { Published: } 28\end{array}$ & $\begin{array}{l}\text { une } 2021 \\
\text { lan. } 2022 \\
\text { Feb. } 2022\end{array}$ \\
\hline $\begin{array}{l}\text { How to cite th } \\
\text { Pieters, W.R., } \\
\text { E., \& Nel, P. (2 } \\
\text { affecting lectu } \\
\text { to stay or leav } \\
\text { Namibia. SA Jc } \\
\text { Human Resou } \\
\text { Management/ } \\
\text { vir Menslikehu } \\
20(0) \text {, a1691. } \\
\text { org/10.4102/s } \\
\text { v20i0.1691 }\end{array}$ & $\begin{array}{l}\text { is article: } \\
\text { Van Zyl, } \\
\text { 022). Factors } \\
\text { rers' decision } \\
\text { e academia, } \\
\text { urnal of } \\
\text { rce } \\
\text { 'SA Tydskrif } \\
\text { Ipbronbestuur, } \\
\text { https://doi. } \\
\text { ajhrm. }\end{array}$ \\
\hline $\begin{array}{l}\text { Copyright: } \\
\text { (C) 2022. The A } \\
\text { Licensee: AOS } \\
\text { is licensed unc } \\
\text { Creative Comn } \\
\text { Attribution Lic }\end{array}$ & $\begin{array}{l}\text { uthors. } \\
\text { IS. This work } \\
\text { ler the } \\
\text { nons } \\
\text { ense. }\end{array}$ \\
\hline Read online: & \\
\hline 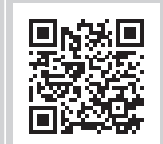 & $\begin{array}{l}\text { Scan this QR } \\
\text { code with your } \\
\text { smart phone or } \\
\text { mobile device } \\
\text { to read online. }\end{array}$ \\
\hline
\end{tabular}

Orientation: Attracting and retaining academic staff needs to become a priority for tertiary institutions.

Research purpose: Instead of spending funds on replacing staff members, tertiary institutions need to invest in interventions to keep staff committed to and embedded into the organisation.

Motivation for the study: Lecturing staff are valuable resources that need to be nurtured, taken care of, and retained to keep tertiary institutions functioning effectively. This study focused on factors that impact lecturing staff's decision to stay at or leave the University of Namibia.

Research approach/design and method: Making use of quantitative research (a questionnaire), data was collected from lecturing staff $(n=242)$ to investigate the relationship between organisational commitment, job embeddedness and turnover intention.

Main findings: Affective commitment, normative commitment, organisational fit and organisational sacrifices reported significant negative relationships with turnover intention. Affective commitment, organisational fit and organisational sacrifice were found to be significant predictors of turnover intention.

Practical/managerial implications: Including lecturing staff in the decision-making process, ensuring that there is an equitable exchange for their labour and being fair during interactions enhances psychological meaningfulness and affective commitment. Providing career development opportunities enhances organisational fit, effectiveness of staff and reduces turnover intention. Assessing the job demands-resources relationship remains of cardinal importance.

Contributions/value-add: Provision of benefits, employees identifying with the organisation and having the needed resources mitigate the demands of the job, reduce exhaustion, enhance levels of commitment and decrease turnover intention.

Keywords: organisational commitment; job embeddedness; predicting turnover intention of academics.

\section{Introduction}

The alarming rate at which academic staff members leave tertiary institutions could result in the ineffective functioning of this profession (Bezuidenhout \&; Cilliers, 2011; Derbew, Gebrekiros, Hailu, Fekade, \& Mekasha, 2014). Theron, Barkhuizen and Du Plessis (2014) indicated that globally, the demand for academics in higher education will continue for the years to come. Not many young academics are joining the ranks of tertiary education and universities still struggle to retain these rare human resources that are very expensive to develop and replace (Soltis, Agneessens, Sasovova, \& Labianca, 2013; Van Schalkwyk, Du Toit, Bothma, \& Rothmann, 2010). Finding ways to retain and utilise them for the advancement of the institution will be beneficial to both parties, namely the institution and the employees. It was observed that younger academics are experiencing a higher level of turnover intention compared with older academics (Gurmessa \& Tefera, 2019). These younger academics are needed for sustainability and continuation of academic institutions:

The changing and unstable workplace and its profoundly negative impact on employee loyalty, morale, motivation and job security have led to a renewed interest in the motives and values that determine individuals' psychological attachment to their organisations and occupations. (Coetzee, Schreuder, \& Tladinyane, 2007, p. 65)

During crisis, employees require additional or extended amounts of support/resources from leaders and the organisation (Ramlachan \& Beharry-Ramraj, 2021). No study in Namibia focusing on these variables is reported and limited literature is available related to academics in Namibia. 
The job demands-resources theory was developed by Bakker and Demerouti (2007) to explain the interaction between the job demands and job resources employees experience at work. Job demands include emotional, mental and physical expectations from work roles or the organisation. Job resources include the psychological, emotional and social resources that not only mitigate the impact of the job demands but also motivate employees towards productivity (Bakker \& Demerouti, 2007). It was found that depending on the interaction between job demands and job resources, employees could experience burnout or motivation/work engagement (Haley, Moster, \& Els, 2013). In line with the organisational equilibrium theory, Perez (2008) and Pieters (2018) observed that when disequilibrium exists within the organisation, employees may find ways to restore equilibrium by reducing their efforts before eventually leaving the organisation.

Firstly, this study will assess the relationship between organisational commitment, job embeddedness and turnover intention amongst lecturing staff in Namibia. Secondly, it will evaluate whether organisational commitment and job embeddedness predict turnover intention of Namibian lecturing staff.

\section{Literature review}

This section aims to discuss key literature regarding turnover intention, organisational commitment and job embeddedness. This section defines these variables, discusses some of the key antecedents and outcomes and how these variables are related. This study also discusses the gap in literature within the Namibian academic context and the investigation focusing on the combination and collective effect of these variables on turnover intention.

\section{Turnover intention}

'Turnover intention reflects the (subjective) probability that an individual will change his or her job within a certain time period' (Sousa-Poza \& Henneberger, 2004, p. 113). Turnover intention is 'an immediate precursor to actually leaving' (Medina, 2012, p. 5). Turnover is 'any permanent loss of employees from an organisation that have to be replaced' (Grobler, Warnich, Carrell, Elbert, \& Hatfield, 2011, p. 667). Based on these definitions, it seems likely that employees who experience turnover intention are likely to leave the organisation.

It was observed that employees do not resign impulsively from organisations, instead they resign after some organisational changes take place that lead to negative jobrelated attitudes (Soltis et al., 2013). Rothmann and Jordaan (2006) found that tertiary institutions have gone through some tremendous changes over the last few years. These changes have led to work-overload which, predicted turnover intention (Pienaar, Sieberhagen, \& Mostert, 2007; Rothmann, Barkhuizen, \& Tytherleigh, 2008). The COVID-19 pandemic caused changes within academia such as blended learning, adding to the current challenges whilst amplifying the challenges related to inequality, skills deficit and digital divide amongst students, academics and parents (Mhlanga, 2021). Many times organisations do not provide the necessary job resources to facilitate these changes to ease the increased work demands. Rothmann et al. (2008) and Marques (2013) indicated that a lack of job resources increases employees' turnover intention. Working under conditions where the job demands outweigh the job resources is likely to lead to emotional exhaustion (Gorgens-Ekermans \& Kotze, 2020; Ladebo, 2009) and work-family conflict (Balogun \& Afolabi, 2019). The interaction between the employee and the organisation influences these job attitudes. Monitoring and regular assessment of job attitudes can help with early diagnosis and intervention.

The decision to work hard for the organisation or to leave the organisation is dependent on the interaction of the employee with the organisation (Perez, 2008; Russell \& Van Sell, 2012). Decision to leave the organisation is impacted by the perceived ease of movement, which is affected by other alternatives outside the organisation and the desire to move is also influenced by job satisfaction and the possibility of internal transfer. If there are many jobs available and the employee has the necessary skills and characteristics that are required, ease of movement will be increased (Perez, 2008; Russell \& Van Sell, 2012). If the organisation is not offering market-related salaries and good employment conditions, which are being offered by other organisations, perceived desirability of movement would be high. Job satisfaction remains an important consideration by the employee in the interaction (Perez, 2008; Russell \& Van Sell, 2012). When the needs of employees are not met, they are likely to experience negative job attitudes and consider leaving the organisation.

Derbew et al. (2014) observed that there is a continuous outflow of academics from the universities in Ethiopia. Theron et al. (2014) highlighted that the need for competent academics will continue into the future. This loss of competent academics results in high staff recruitment costs, low staff morale (Derbew et al., 2014), negative experience and growth of students. The staff who remain at the organisation may also be required to take on additional duties (role overload) whilst these vacancies are being filled. Akpey-Mensah and Muchie (2020) indicated that the war on talent for competent and knowledgeable academics is ongoing and that these knowledgeable academics provide a competitive advantage for the institution. This emphasises the need for regular monitoring, being alert of the changes in job attitudes and preventing these negative consequences related to turnover.

Occupational stress amongst academics will continue to increase if no strategies and mechanisms are implemented to address the demands of the profession (Du Plessis, 2020). Role overload predicted turnover intention of employees (Pienaar et al., 2007). When employees have to perform many tasks (more tasks with less time) or some challenging tasks (complex tasks with same time) they will experience turnover intention (Pienaar et al., 2007). The degree to which work overload impacts turnover intention is moderated by social support. Work overload was found to be one of the strongest 
factors, which cause stress for academics (Rothmann et al., 2008). Apart from having to adjust to constant transformation of tertiary institutions, increased teaching and research demands and the diversity of students attending the universities, academics are further stressed by the poor quality of primary and secondary educational background of the students (Rothmann et al., 2008). Employees who are emotionally exhausted experience lower levels of commitment and will eventually resign (Ladebo, 2009). Apart from the push factors (pushing employees out of the organisation), a lack of career development opportunities in the organisation also contributes to the intention to leave.

It was found that employees' intention to leave was mostly attributed to lack of career development opportunities within the organisation (Lavoie-Tremblay et al., 2010). According to Janik and Rothmann (2015), work-role fit indirectly affected employees' level of turnover intention because of the lack of psychological meaningful experiences for those employees. Employees who experience healthy relationships at work would experience lower levels of turnover intention as compared with employees who do not experience good co-worker and supervisor relations (Janik \& Rothmann, 2015). Relatedness can be regarded as a resource, reducing turnover intention.

It is important for organisations to have both internal and external equity when it comes to pay and benefits offered to employees (Washeya \& Furst, 2021). Base pay (marketrelated salary) was regarded as the strongest predictor of job satisfaction and is also one of the top factors for attracting and retaining staff members at work (Snelgar, Renard, \& Venter, 2013). An invaluable finding was that whilst low pay may influence an employee to leave the organisation higher pay may be unlikely to keep employees from leaving the organisation. It was emphasised that intrinsic rewards were as important as pay (Smit, Stanz, \& Bassin, 2015). These benefits influence job satisfaction of employees.

Khawaldeh, Al Muala and Al Ziadat (2014) found that job satisfaction directly influences turnover intention. Some of the factors found to improve job satisfaction include training, participation in conferences, and monthly or annual incentives. Reducing turnover intention by enhancing job satisfaction may cost the organisation less money compared to the cost of dealing with actual turnover.

It was found that turnover leads to a loss of resources and increases costs (Zhao et al., 2012). These costs include advertising of vacancies within the organisation, profit losses during the vacancy period, work duties to be divided amongst staff members who already have a full-work load, costs related to personnel recruitment and selection, developing the employees to a level of effective functioning and all these costs are repeated when an employee leaves the organisation. Despite all these costs associated with turnover, organisations still tend to underestimate the appalling implications associated with turnover.

\section{Organisational commitment}

Organisational commitment can be defined as an employee's willingness and identification with an organisation, wanting to remain at the organisation and investing efforts towards the achievement of organisational goals (Allen \& Meyer, 1996; Luthans, 2005). Robbins (2003) indicated that organisational commitment may also be defined as identification with organisational goals and objectives. The bigger the overlap between an employees' goal and the organisations' goals and objectives, the higher the level of organisational commitment (Robbins, 2003). Employees become committed to the organisation because of different reasons, thus they experience different types of commitment.

Organisational commitment consists of three types of commitment. Continuance commitment can be described as commitment towards the organisation in relation to the personal benefits associated with remaining at the organisation. Continuance commitment flows into normative commitment. Normative commitment can be defined as the type of commitment that relates to feelings of obligation to remain at the organisation (Allen \& Meyer, 1996; Meyer, Allen, \& Smith, 1993). Affective commitment is the emotional attachment, which the employee has for the organisation, the work that they do, and they feel the need to contribute effectively towards the success of the organisation and wish to remain part of it. Affective commitment is the type of commitment that enhances productivity levels within the organisation (Allen \& Meyer, 1996; Meyer et al., 1993). The next section will focus on the different factors that influence organisational commitment.

Mor Barak, Nissly and Lewin (2001) and Du Plooy and Roodt (2010) observed that employees leave because of organisational or job-based factors. Managers and policy developers can influence voluntary turnover or even prevent it from happening. It was found that role ambiguity negatively affected organisational commitment (Dhurup \& Mahomed, 2011). When lecturing staff are not sure about their roles within the organisation, they would most likely be unable to contribute effectively to the organisation's goals and experience lower levels of organisational commitment.

On the other hand, procedural and distributive justice was found to influence organisational commitment of employees (Akuzum, 2014). If employees regard organisational procedures to be fair and when benefits and punishment are fairly and equitably distributed, employees may experience higher levels of organisational commitment (Akuzum, 2014). Apart from organisational justice, other policies and procedures may also influence organisational commitment.

Job enrichment, the provision of the necessary work resources and support, having supportive colleagues and supervisors, experiencing co-worker involvement, enjoying positive managerial practices, organisational support (relatedness) and autonomy satisfaction would result in organisational commitment (Ladebo, 2008, 2009; Rothmann, Diedericks, \& Swart, 2013; Smit et al., 2015). These are aspects of the 
organisation that can be enhanced or addressed with the needed policies and improved procedures. Organisational commitment can also hold other benefits for the employees and the organisation.

A positive relationship was found between affective commitment, well-being and work engagement (Field \& Buitendach, 2011). If organisations enhance organisational commitment (affective commitment), employees would also become healthier and more engaged in their work (Field \& Buitendach, 2011). Job embeddedness is another factor that has not been investigated extensively yet seems to play a key role in the turnover intention levels of employees. The following section will focus on defining job embeddedness and discuss some of the key antecedents and outcomes related to job embeddedness.

\section{Job embeddedness}

Job embeddedness is investigated as a variable that focuses on why employees remain at work (Mitchell, Holtom, Lee, Sablynski, \& Erez, 2001). It is not only important to understand why employees resign from the organisation but also what factors influence them to remain (Holtom \& Inderrieden, 2006; Mensele \& Coetzee, 2014). Job embeddedness is part of the forces that impact the employees' decision to stay with an organisation. This construct is one that looks at on- and off-thejob influences. Job embeddedness is regarded as the employee's perception about the fit, links and sacrifices (Mensele \& Coetzee, 2014). Job embeddedness consists of the fit, links and sacrifice thus this study will evaluate these dimensions. Fit is related to the employees' perceived match between himself or herself and the organisation, what the job requires and the other employees within the organisation. If employees see that their skills and abilities match the requirements of the job, organisation and community they are more likely to also be better performers compared with employees who do not perceive a good fit (Chinomona, Dhurup, \& Chinomona, 2013). Links are the relationships employees develop with other employees or the organisation. Sacrifice is the losses an employee would endure when planning to leave the organisation; these include the benefits linked to being a member of the organisation or being related to the organisation (Holtom \& Inderrieden, 2006). The links between these dimensions of job embeddedness will be further discussed in the following section.

Holmes, Chapman and Baghurst (2013) found that employees who are not valued owing to lack of training and mentoring, knowledgeable leadership and communication are likely to resign. The weaker the fit and links between the employees and the organisation, the lower the sacrifice and cost of leaving to the employees (Holmes et al., 2013). Organisations need to keep abreast of the needs of employees and factors that will retain them or motivate them to stay (job embeddedness).

The formal and informal relations/ties (whom to ask for advice or help with a work-related task) employees experience within theorganisationinfluencetheiroverall levelofjobembeddedness (Soltis et al., 2013). It was found that employees being frequently approached by many other colleagues for work-related advice increased their level of turnover intention significantly (Soltis et al., 2013). The perception of employees plays a significant role in assessing this as a mentoring opportunity or as additional workload. Being available for frequent advice can add to the workload. The following section will focus on the relationship between the variables in this study.

\section{Organisational commitment, job embeddedness and turnover intention}

The global economy is becoming more knowledge-driven and when such knowledge is in short supply it gives organisations, which have employees with such knowledge, a competitive advantage (Takawira, 2012). Assessing how job embeddedness influences turnover intention is important in assisting tertiary institutions to retain knowledgeable staff in higher education (Takawira, 2012). Knowing what keeps employees at the organisation (pull factors) can be maintained or enhanced to retain employees.

Because of the emotional identification (affective commitment) to the organisation, service staff employees chose to remain at work (Van Dyk, Coetzee, \& Tebele, 2013). Affective commitment is a retention factor (employees want to experience affective commitment) thus, these employees would experience fit and links within the organisation and a high level of perceived sacrifice when planning to leave (Van Dyk et al., 2013). If black employees experience fit, they would have a stronger understanding of commitment, wanting to stay with the organisation (Ferreira \& Coetzee, 2013). Fit is also associated with affective commitment (identifying with the workplace), wanting to remain at the workplace (organisational commitment) and increasing effort (work engagement) amongst nurses (Zhao et al., 2012). Based on the literature discussed, a relationship is confirmed between job embeddedness and organisational commitment within these different contexts.

A negative relationship was found amongst employees working at a state-owned enterprise in South Africa between commitment and turnover intention (Burger, 2014). When employees experience a psychological identification with an organisation, they remain committed and are less likely to resign (Burger, 2014). Identifying with the organisation encourages positive work attitudes and behaviour towards the organisation.

According to Ryan and Harden (2014), job embeddedness is a psychological force that has the potential to influence information technology (IT) workers to remain within the organisation as opposed to leaving (employee turnover). It is also observed that organisations need to be alerted to the fact that working environment changes could influence the degree of embeddedness and eventually possible voluntary employee turnover (Ryan \& Harden, 2014). Thus, tertiary institutions also need to remain vigilant on how changes affect employees' embeddedness levels. 
Job embeddedness predicted turnover intention better than work engagement amongst tertiary institution employees (Takawira, Coetzee, \& Schreuder, 2014). A negative relationship was found between links and turnover intention (Chang et al., 2013; Janik \& Rothmann, 2015; Marques, 2013; Takawira et al., 2014; Wai, Dandar, Radosevich, Brubaker, \& Kuo, 2014). When surgical staff, tertiary institution staff or teachers experience good interactions with supervisors and colleagues, they are likely to remain at work. Relatedness is regarded as a resource. Marques (2013), in her Namibian study, found that relations with colleagues were regarded as one of the strongest factors that influenced turnover intention of academic staff members (administrative and lecturing staff). It was found by Zhao et al. (2012) that high levels of job embeddedness increased loyalty towards the organisation (organisational commitment) and in turn reduced turnover intention for nurses.

The relationship between organisational commitment, job embeddedness and turnover intention has been established in different countries amongst different types of employees, however limited literature exists that focuses on all these dimensions and their predictability as a collective. Limited studies focus specifically on academic staff (excluding administrative staff) and even less studies in the Namibian context.

The following hypotheses were tested in this study:

Hypothesis 1a: Affective, continuance and normative commitment are negatively related to turnover intention.

Hypothesis $1 \mathrm{a}^{\circ}$ : Affective, continuance and normative commitment are not negatively related to turnover intention.

Hypothesis 2a: Organisational fit, links and sacrifices are negatively related to turnover intention.

Hypothesis $2 \mathrm{a}^{\mathbf{0}}$ : Organisational fit, links and sacrifices are not negatively related to turnover intention.

Hypothesis 3a: Affective, continuance and normative commitment, organisational fit, links and sacrifices are significant predictors of turnover intention.

Hypothesis $3 \mathbf{a}^{\circ}$ : Affective, continuance and normative commitment, organisational fit, links and sacrifices are not significant predictors of turnover intention.

\section{Methodology \\ Design}

This study used a questionnaire (quantitative design, survey research). Using a questionnaire, information was collected to compare the relationship between the variables under investigation. This study focused on employees (lecturers) working at the University of Namibia (UNAM). The researchers distributed and collected questionnaires, allowing some time for the questionnaires to be completed during the spare time of the participants.

\section{Participants}

By using convenience sampling, all lecturing staff members working at UNAM who were willing and available were approached for participation (Creswell, 2003). A total of 242 questionnaires were completed and returned. This accounts for $81 \%$ of the total 300 questionnaires that were distributed. The sample consisted of $n=242$ lecturers, 114 males and 128 females; additional information is presented here.

\section{Measuring instruments}

\section{Biographical questionnaire}

The researchers used a biographical section specifically related to gender, age, tenure at UNAM, highest qualification obtained and rank within the organisation (see Table 1).

The Organisational Commitment Questionnaire (OCQ) by Allen and Meyer (1996) was used to measure organisational commitment. By using the 18 -item version (six items per dimension), this study assessed normative, affective and continuance commitment (Brown, 2003). It was a selfreported questionnaire that used a response scale (1 - strongly disagree to 5 - strongly agree). Sample items included for continuance ('one of the few negative consequences of leaving this organisation would be the scarcity of available

TABLE 1: Biographical details of sample.

\begin{tabular}{|c|c|c|}
\hline Description & Frequency & Percentage \\
\hline \multicolumn{3}{|l|}{ Sex } \\
\hline Male & 114 & 47.1 \\
\hline Female & 128 & 52.9 \\
\hline Total & 242 & 100.0 \\
\hline \multicolumn{3}{|l|}{ Age } \\
\hline $24-28$ & 12 & 5.0 \\
\hline 29-31 & 10 & 4.1 \\
\hline $32-35$ & 31 & 12.8 \\
\hline $36-40$ & 37 & 15.3 \\
\hline $41-45$ & 23 & 9.5 \\
\hline $46-50$ & 31 & 12.8 \\
\hline 51 and older & 97 & 40.1 \\
\hline Missing values & 1 & 0.4 \\
\hline Total & 242 & 100.0 \\
\hline \multicolumn{3}{|c|}{ Tenure (UNAM) (in years) } \\
\hline Less than 1 & 25 & 10.3 \\
\hline $1-2$ & 31 & 12.8 \\
\hline $3-4$ & 31 & 12.8 \\
\hline $5-6$ & 55 & 22.7 \\
\hline $7-8$ & 16 & 6.6 \\
\hline 9 and more & 81 & 33.5 \\
\hline Missing values & 3 & 1.2 \\
\hline Total & 242 & 100.0 \\
\hline \multicolumn{3}{|c|}{ Highest qualification obtained } \\
\hline Honours degree & 29 & 12.0 \\
\hline Master's degree & 129 & 53.3 \\
\hline $\mathrm{PhD}$ & 72 & 29.7 \\
\hline Post-doctoral & 12 & 5.0 \\
\hline Total & 242 & 100.0 \\
\hline \multicolumn{3}{|l|}{ Rank } \\
\hline Assistant Lecturer & 26 & 10.7 \\
\hline Lecturer & 156 & 64.5 \\
\hline Senior Lecturer & 36 & 14.9 \\
\hline Associate Professor & 15 & 6.2 \\
\hline Full Professor & 9 & 3.7 \\
\hline Total & 242 & 100.0 \\
\hline
\end{tabular}

UNAM, University of Namibia. 
alternatives'), normative ('I would feel guilty if I leave my organisation right now') and affective ('I do not feel like "part of the family" at my organisation') commitment. Cronbach's alphas previously found for organisational commitment include affective commitment 0.71 , normative commitment 0.71 and continuance commitment 0.71 (Pieters, 2015).

The Job Embeddedness Scale (JES) (Mitchell et al., 2001) assessed links, fit and sacrifice (on the job and within the community). Responses ranged from 1 (strongly disagree) to 6 (strongly agree). It measured links ('how many co-workers do you interact with regularly?'), fit ('my job utilises my skills and talents well') and sacrifice ('I would sacrifice a lot if I left this job'). Acceptable alphas were reported by Ferreira and Coetzee (2013) (0.84 organisational fit, 0.77 organisational links, 0.87 organisational sacrifice). This study focused exclusively on the organisational dimensions.

To measure turnover intention, the Turnover Intention Scale (TIS - 6) was used (Bothma \& Roodt, 2013). It used a 5 point scale ranging from 1 (never or to no extent) to 5 (most of the time or to a large extent). Bothma and Roodt (2013) found Cronbach's alpha of 0.80 .

\section{Analysis}

This study used descriptive statistics to describe the data. Inferential statistics was used to aid in explaining the relationship between the variables and make inferences. Estimates of reliability, Pearson's product-moment correlation, and stepwise multiple regression analysis was used (SPSS, 2016). The data were normally distributed, thus parametric statistics was used.

\section{Ethical considerations}

Ethical clearance was obtained from the University of the Free State; University of Namibia, UFS-HSD2015/0562, 24 November 2015.

\section{Results}

\section{Descriptive statistics and correlations}

The mean, standard deviation (s.d.), Cronbach's alpha and correlations were analysed and reported in Table 2.
It was observed by Nunnally (1978) that acceptable Cronbach's alphas need to be higher than 0.70, however Resi and Judd (2000) later indicated that acceptable Cronbach's alphas can range between 0.60 and 0.80 for research. These Cronbach's alpha results indicate that the instruments were reliable for measuring the variables in this study.

Affective commitment reported a relationship with continuance commitment $(r=-0.13, p<0.05$; small), normative commitment $(r=0.61, p<0.05$; large), organisational fit $(r=0.69, p<0.05$; large), organisational links $(r=0.33, p<0.05$; medium), organisational sacrifice $(r=0.50, p<0.05 ;$ large $)$ and turnover intention $(r=-0.49$, $p<0.05$; medium). The negative relationship between affective commitment and turnover intention reject hypothesis $1 \mathrm{a}^{\circ}$.

Continuance commitment reported a relationship with normative commitment $(r=0.14, p<0.05$; small $)$, organisational fit $(r=-0.08, p<0.05$; small), organisational links ( $r=-0.07, p<0.05$; almost no relationship), organisational sacrifice $(r=0.03, p<0.05$; almost no relationship) and turnover intention $(r=0.15, p<0.05$; small). The positive relationship between continuance commitment and turnover intention fails to reject hypothesis $1 \mathrm{a}^{\circ}$.

Normative commitment reported a relationship with organisational fit $(r=0.52, p<0.05$; large), organisational links $(r=0.34, p<0.05$; medium), organisational sacrifice $(r=0.44, p<0.05$; medium $)$ and turnover intention $(r=-0.36$, $p<0.05$; medium). The negative relationship between normative commitment and turnover intention reject hypothesis $1 \mathrm{a}^{\mathrm{o}}$.

Organisational fit reported a relationship with organisational links $(r=0.37, p<0.05$; medium), organisational sacrifice $(r=0.52, p<0.05$; large $)$ and turnover intention $(r=-0.41$, $p<0.05$; medium). The negative relationship between organisational fit and turnover intention reject hypothesis $2 \mathrm{a}^{\circ}$.

Organisational links reported a relationship with organisational sacrifice $(r=0.19, p<0.05$; small $)$ and turnover intention $(r=-0.10, p<0.05$; small). The negative relationship between organisational links and turnover intention reject hypothesis $2 \mathrm{a}^{\circ}$.

TABLE 2: Descriptive statistics and Pearson correlation coefficient.

\begin{tabular}{|c|c|c|c|c|c|c|c|c|c|c|}
\hline Variable & M & s.d. & A & 1. & 2. & 3. & 4. & 5. & 6. & 7. \\
\hline Affective commitment & 21.35 & 4.34 & 0.80 & - & - & - & - & - & - & - \\
\hline Continuance commitment & 17.13 & 4.65 & 0.75 & $-0.13 *$ & - & - & - & - & - & - \\
\hline Normative commitment & 19.95 & 4.47 & 0.77 & $0.61 \ddagger$ & $0.14 *$ & - & - & - & - & - \\
\hline JE- Organisational fit & 40.33 & 7.34 & 0.90 & $0.69 \ddagger$ & $-0.08 *$ & $0.52 \ddagger$ & - & - & - & - \\
\hline JE- Organisational links & 10.98 & 4.03 & 0.71 & $0.33 * \dagger$ & $-0.07 *$ & $0.34 * \dagger$ & $0.37 * \dagger$ & - & - & - \\
\hline JE- Organisational sacrifice & 40.85 & 8.07 & 0.87 & $0.50 \%$ & 0.03 & $0.44 * \dagger$ & $0.52 \%$ & $0.19 *$ & - & - \\
\hline Turnover intention & 21.47 & 5.21 & 0.69 & $-0.49 * \dagger$ & $0.15 *$ & $-0.36 * \dagger$ & $-0.41 * \dagger$ & $-0.10 *$ & $-0.37 * \dagger$ & - \\
\hline
\end{tabular}

$\mathrm{JE}$, job embeddedness; s.d., standard deviation.

Statistically significant: $p \leq 0.05$.

$\dagger$, Practically significant correlation (medium effect): $0.30 \leq r \leq 0.49$.

\$, Practically significant correlation (large effect): $r^{3} 0.50$. 
Organisational sacrifice reported a negative relationship with turnover intention ( $r=-0.37, p<0.05$; medium). The negative relationship between organisational sacrifice and turnover intention reject hypothesis $2 \mathrm{a}^{\circ}$.

\section{Multiple regression analyses}

Multiple regression analyses were utilised to test hypothesis $3 \mathrm{a}^{\circ}$. The first model utilised turnover intention as the dependent variable, with affective commitment, normative commitment as the dependent variables. In the second model, organisational fit and organisational sacrifice was added as part of the independent variables (model 2). Results are presented in Table3.Continuance commitmentand links(jobembeddedness) were excluded from the regression analysis because the correlation with turnover intention was less than 0.30 .

Focusing on Table 3, normative and affective commitment in step one of the regression analysis presented a statistically significant model $\left(F_{(2.239)}=45.87 ; p<0.00\right)$ and explained $27.7 \%$ of the variance. Affective commitment $(b=0.46 ; t=6.68 ; p<0.00)$ is a significant predictor of turnover intention in this model. Normative commitment $(b=0.09 ; t=1.35 ; p<0.18)$ was found to be an insignificant predictor of turnover intention in this model. In model 2, organisational fit and organisational sacrifice was introduced to produce a significant model $\left(F_{(4.237)}=29.24\right.$; $p<0.00)$ and accounted for $33 \%$ of the variance in turnover intention. Affective commitment $(b=0.29 ; t=3.51 ; p<0.00)$, organisational fit $(b=0.18 ; t=2.40 ; p<0.02)$ and organisational sacrifice $(b=0.19 ; t=2.87 ; p<0.00)$ were significant predictors of turnover intention in this model. This result rejects hypothesis $3 \mathrm{a}^{\circ}$ of the study. Normative commitment $(b=0.03 ; t=0.39$; $p<0.67)$ was an insignificant predictor of turnover intention. This result fails to reject hypothesis $3 a^{\circ}$ of the study.

\section{Discussion}

This investigation aimed at exploring organisational commitment and job embeddedness factors that influence

TABLE 3: Multiple regression with turnover intention the dependent variable and affective commitment, normative commitment (organisational commitment) and organisational fit, organisational sacrifice (job embeddedness) the independent variables.

\begin{tabular}{lccccccccc}
\hline Model & $\begin{array}{c}\text { Unstandardised } \\
\text { coefficients } \\
\boldsymbol{B} \text { s.e. }\end{array}$ & $\begin{array}{c}\text { Standardised } \\
\text { coefficients }(\boldsymbol{\beta})\end{array}$ & $\boldsymbol{t}$ & $\boldsymbol{p}$ & $\boldsymbol{F}$ & $\boldsymbol{R}^{\mathbf{2}}$ & $\boldsymbol{\Delta \boldsymbol { R } ^ { \mathbf { 2 } }}$ \\
\hline $\mathbf{1}$ & & & & & & & & & \\
(Constant) & 7.42 & 1.53 & - & 4.85 & 0.00 & 45.87 & 0.28 & 0.271 \\
Aff_OC & 0.56 & 0.08 & 0.46 & 6.68 & $0.00 *$ & - & - & - \\
Norm_OC & 0.11 & 0.08 & 0.09 & 1.35 & 0.18 & - & - & - \\
$\mathbf{2}$ & & & & & 0.00 & 29.24 & 0.33 & 0.319 \\
(Constant) & 3.38 & 1.75 & - & 1.93 & 0.06 & - & - & - \\
Aff_OC & 0.34 & 0.10 & 0.29 & 3.51 & $0.01 * *$ & - & - & - \\
Norm_OC & 0.03 & 0.08 & 0.03 & 0.39 & 0.70 & - & - & - \\
Fit_JE & 0.13 & 0.05 & 0.18 & 2.40 & $0.02 *$ & - & - & - \\
Sacrifice_JE & 0.12 & 0.04 & 0.19 & 2.87 & $0.00 * *$ & - & - & - \\
\hline
\end{tabular}

$t$, test; $p$, probability value; $F$, overall significance; $R^{2}$, percentage variance explained; $\Delta R^{2}$ change in percentage variance explained; $B$, regression coefficient; s.e., standard error; JE, job embeddedness; Aff, affective; Norm, normative.

$*, p \leq 0.05 ; * *, p \leq 0.01$. lecturing staff to remain or leave UNAM. Continuance commitment reported a positive relationship with turnover intention. According to the staff development policy, UNAM pays for further studies and provides studying benefits to family members of staff members, it could be a factor that retains employees at UNAM. Having a positive identification with the workplace, aims and objectives, employees would be willing to remain and work towards these goals and objectives (affective commitment) (Du Plooy \& Roodt, 2010). Working for an organisation that provides employees with good benefits and working conditions, enhances continuance commitment, which has a negative relationship with turnover intention. However, this study found a positive association between continuance commitment and turnover intention. Literature indicates that the benefits and working conditions should actually keep lecturing staff at UNAM but in this instance continuance commitment has a positive relationship with turnover intention. This could be because of lecturing staff's perception of employability or that they do not regard these benefits or working conditions as important enough to stay, which was found by Russell and Van Sell (2012).

Organisational fit, links and sacrifice reported a negative relationship with turnover intention. These results reject hypothesis $2 \mathrm{a}^{\circ}$ of this study. Employees who are provided with the needed job resources (Marques, 2013), matching the expected duties (Rothmann et al., 2008), they would stay at work. Working for an organisation that employees identify with, an organisation that has similar values and objectives as the employee are likely to ensure that employees want to remain at the organisation (Holmes et al., 2013). Having good interactions and relationships with colleagues and supervisors ensures that employees experience positive emotions, motivating them to want to remain at the organisation (Janik \& Rothmann, 2015; Soltis et al., 2013). A negative relationship was found between organisational sacrifices and turnover intention. When UNAM can provide employees with the needed benefits, job resources, healthy working environment (Smit et al., 2015) and work-related factors that positively impact job satisfaction (Khawaldeh et al., 2014; Lavoie-Tremblay et al., 2010), employees are likely to want to stay at the organisation (Snelgar et al., 2013). These employees who become more embedded experience higher levels of work engagement (Zhao et al., 2012).

Continuance commitment and organisational links were not part of the regression analyses because the correlation with turnover intention is below the required limit (0.30). Affective commitment, organisational fit and sacrifice are significant predictors of turnover intention of lecturing staff at UNAM. Identifying with the workplace, experiencing a positive match between expectations and resources (Janik \& Rothmann, 2015) and being provided with the needed resources, benefits and a conducive working environment, staff may be willing to remain at UNAM. It makes financial and business sense to retain academic staff instead of replacing and retraining new staff to levels of effective functioning. Normative commitment was found to be an insignificant predictor of turnover intention for this study. 


\section{Practical implications}

This study may point to factors that influence the retention (through felt turnover intention) of academic staff in general, at UNAM. Tertiary institutions need to be alert and attentive to the needs of lecturing staff. According to the threedimensional model of organisational commitment, personal characteristics (what employees' value in terms of work, what kind of work they find meaningful), satisfaction of basic psychological needs (autonomy, relatedness, competence), working experience and competence affects affective commitment. It is important for UNAM to know what employees' values are and what kind of work enhances their meaningfulness, this may add to their levels of affective commitment and organisational fit. Knowing this will ensure that the work is structured in such a way to enhance meaningfulness, ensure that the organisational objectives do not conflict with employee values or find ways to align these conflicting values. Allowing employees opportunities to share their views, to make decisions within the organisation; safeguarding healthy working relationships between colleagues and supervisors and ensuring that employees have sufficient resources to match the job demands and the required skills and competencies to execute their work roles, positively influence their affective commitment. Furthermore, providing a healthy interaction at work, ensuring that conflict resolution is performed amicably and employees have a platform to voice their concerns and procedures to resolve such issues will positively impact affective commitment. The University of Namibia needs to make sure that lecturing staff are provided with the needed benefits, experience a good fit between expectations and resources, and fit between skills and work duties. The University of Namibia needs to assess the workload of lecturing staff so that they do not experience work overload, burnout or intend to leave. To avoid burnout and still maximise the productivity of staff members, workload and general health should be monitored closely.

In order to avoid emotional exhaustion, it is advised that wellness programmes should be implemented and functioning. Through these wellness programmes lecturing staff may be able to reduce stress, live healthy and active lives to reduce emotional exhaustion. With the help of these wellness programmes, healthy staff members may experience a higher level of organisational commitment and lower turnover intention.

It is also vital for the employees to have good relations with their colleagues and supervisors. Good relations are fostered between lecturing staff, colleagues and supervisors, they are enhancing affective commitment and also reducing turnover intention. In order to retain all these benefits that comes with being a member of UNAM, lecturing staff will experience affective commitment and lower levels of turnover intention.

Considering that normative commitment flows from continuance commitment, UNAM needs to be aware of the necessities and expectations of employees. By providing lecturing staff with what they need ensures that they remain committed towards the organisations and want to perform on behalf of the workplace. The University of Namibia needs to conduct an assessment to identify what it is that lecturing staff want and what they need to remain satisfied at the university.

Providing employees with training and development opportunities will improve their working experience, enhance their level of competence, increase affective commitment, improve organisational fit and reduce turnover intention. Equipping employees with the required skills and abilities enhances their level of perceived competence, makes them want to take on more challenging tasks, improve their working experience and contribute positively to the success of the organisation. Another way to enhance organisational fit can be by assessing the skills and abilities of the lecturing staff, identify where they would function best and what kinds of skills need to be invested in. By rotating staff to teach different modules they could identify a module that suits their style of teaching or knowledge better. Lecturers prefer teaching certain modules for many years and at times may become complacent at teaching these modules. Rotating modules every third year can ensure that lecturers remain relevant, up to date and passionate about the different aspects of their discipline.

Staff members need to grow and be exposed to career development opportunities. When staff members become stagnant, their teaching abilities become outdated, fail to inspire the students and staff lose interest/passion in what they do. Exposing staff members to career development opportunities enhances their productivity levels and increases their intention to remain at UNAM.

This study also found organisational sacrifice to be a key predictor of turnover intention. Understanding what UNAM lecturing staff want or need will ensure that the university will be able to keep lecturing staff satisfied, content and wanting to remain as part of the organisation. Once the institution caters to the needs to the lecturing staff, lecturers would also be more committed and work for the organisation.

\section{Limitations and recommendations}

This study has some limitations. This study only focused on organisational commitment, job embeddedness and turnover intention. Turnover intention may also be affected by many other variables that were excluded from this study. This is also highlighted by the multiple regression analysis done; indicating that organisational commitment and job embeddedness explains 33\% of the changes in turnover intention of the target sample. Considering that the sample was rather small, the findings may not be generalised to the population. It is thus recommended to conduct a similar study by focusing on the entire lecturing staff at UNAM. The study made use of questionnaires; 
future studies may consider using a qualitative design (interviews, focus group discussions). A qualitative study may also help to add to the deeper understanding of turnover intention.

\section{Conclusion}

To retain lecturing staff, it remains critical for tertiary institutions to make drastic efforts to retain their staff members. This study confirms the significant impact of affective commitment on turnover intention. Affective commitment was one of the most significant predictors of turnover intention. This study identified the importance of organisational fit, matching resources to job demands; matching skills to job roles and how it impacts on affective commitment. Organisational links, healthy working relationships between colleagues and supervisors as well as the benefits associated with membership at UNAM also impacted on affective commitment.

Continuance commitment, normative commitment and organisational links were found to be insignificant predictors of turnover intention. Normative commitment relates positively to affective commitment and affective commitment predicts turnover intention. Organisational links reported a positive association with affective commitment, impacting on turnover intention. Organisational links also reported a positive relationship with turnover intention, normative commitment and organisational fit. Even though these variables are not significant predictors, they do impact turnover intention through other dimensions in this study.

\section{Acknowledgements Competing interests}

The authors have declared that no competing interest exists.

\section{Authors' contributions}

W.R.P. was responsible for conceptualisation, article writing, data collection, review and correspondence. E.V. was involved in conceptualisation, supervision, administration and funding acquisition. P.N. was involved in conceptualisation, data analysis, editing and supervision.

\section{Funding information}

This research received no specific grant from any funding agency in the public, commercial or not-for-profit sectors.

\section{Data availability}

Data sharing is not applicable to this article as no new data were created or analysed in this study.

\section{Disclaimer}

The views and opinions expressed in this article are those of the authors and do not necessarily reflect the official policy or position of any affiliated agency of the authors.

\section{References}

Akpey- Mensah, T.L., \& Muchie, M. (2020). Application of Ubuntu as innovative human resources practice to retain academic staff at Sunyani Technical University, Ghana. African Journal of Indigenous Knowledge Systems, 19(1), 47-57.

Akuzum, C. (2014). The effect of organisational justice and organisational cynicism on the organisational commitment: An application in primary education institutions. Mevlana International Journal of Education, 4(3), 48-68.

Allen, N.J., \& Meyer, J.P. (1996). Affective, continuance and normative to the organisation: An examination of the construct validity. Journal of Vocational Behavior, 49, 252-276. https://doi.org/10.1006/jvbe.1996.0043

Bakker, A.B., \& Demerouti, E. (2007). The job demands-resources model: State of the art. Journal of Managerial Psychology, 22(3), 309-323. https://doi. org/10.1108/02683940710733115

Balogun, A.G., \& Afolabi, O.A. (2019). Examining the moderating roles of job demands and resources on the relation between work engagement and work-family conflict. South African Journal of Psychology, 49(4), 479-490. https://doi. org/10.1177/0081246318818382

Bezuidenhout, A., \& Cilliers, F. (2011). Age, burnout, work engagement and sense of coherence in female academics at two South African universities. South African Journal of Labour Relations, 35(1), 61-80. https://doi.org/10.4102/ sajip.v36i1.872

Bothma, C.F.C., \& Roodt, G. (2013). The validation of the turnover intention scale. South African Journal of Human Resource Management, 11(1), 1-12. https://doi. org/10.4102/sajhrm.v11i1.507

Brown, B.B. (2003). Employees organizational commitment and their perception of supervisors' relationship-oriented and task-oriented leadership behaviors. Unpublished PhD dissertation in Human Development. Blacksburg, VA: Virginia Polytechnic Institute and State University.

Burger, E. (2014). Investigating high turnover intention and a diminished level of organisational commitment as antecedents of accidents. Unpublished Masters Dissertation. Johannesburg: Stellenbosch University.

Chang, W.A., Wang, Y., \& Huang, T. (2013). Work design-related antecedents of turnover intention: a multilevel approach. Human Resource Management, 52(1), 1-26.

Chinomona, R., Chinomona, E., \& Dhurup, M. (2013). Does employee perceptions of fit to job fit to organisation and fit to community influence job performance? The case of Zimbabwe's manufacturing sector. South African journal of Human Resource Management, 11(1), 1-10. https://doi. Journal of Human Resource
org/10.4102/sajhrm.v11i1.475

Coetzee, M., Schreuder, D., \& Tladinyane, R. (2007). Organisational commitment and its relation to career anchors. Southern African Business Review, 11(1), 65-86.

Creswell, J.W. (2003). Research design: Qualitative, quantitative, and mixed methods approaches (2nd ed.). Thousand Oaks, CA: Sage.

Derbew, M., Gebrekiros, D.H.H., Hailu, A.D., Fekade, D., \& Mekasha, A. (2014). Turnover rate of academic faculty at the College of Health Sciences, Addis Ababa University: A 20-year analysis (1991-2011). Annals of Global Health, 80(3), 236-237. https://doi.org/10.1016/j.aogh.2014.08.197

Du Plessis, M. (2020). Model of coping with occupational stress of academics in a South African higher education institution. South African Journal of Industrial Psychology, 46(1), 1-11. https://doi.org/10.4102/sajip.v46i0.1714

Du Plooy, J., \& Roodt, G. (2010). Work engagement, burnout and related constructs as predictors of turnover intentions. South African Journal of Industrial Psychology, 36(1), 1-13. https://doi.org/10.4102/sajip.v36i1.910

Dhurup, M., \& Mahomed, F.E. (2011). Role ambiguity, role conflict and work overload and their influence on job satisfaction of sports facilitators in public schools in the Vaal Triangle, South Africa. African Journal for Physical, Health Education, Recreation and Dance, 17, 172-188.

Ferreira, N., \& Coetzee, M. (2013). The influence of job embeddedness on black employees' organisational commitment. Southern African Business Review, 17(3), 239-255.

Field, L.K., \& Buitendach, J.H. (2011). Happiness, work engagement and organisationa commitment of support staff at a tertiary education institution in South Africa. South African Journal of Industrial Psychology, 37(1), 1-10. https://doi. org/10.4102/sajip.v37i1.946

Gorgens-Ekermans, G., \& Kotze, C. (2020). Insights into the burnout development process: A study of call centre representatives. Management Dynamics, 29(2), 19-35.

Grobler, P.A., Warnich, S., Carrell, M.R., Elbert, N.F., \& Hatfield, R.D. (2011). Human resource management in South Africa (4th ed.). Beijing: Cengage Learning EMEA.

Gurmessa, Z.B., \& Tefera, O. (2019). The effect of age on academic staff retention in higher education sector in Sub-Saharan Africa. Journal of Educational Studies, 18(1), 100-121.

Haley, L., Moster, K., \& Els, C. (2013). Burnout and work engagement for different age groups: Examining group-level differences and predictors. Journal of Psychology in Africa, 23(2), 283-296. https://doi.org/10.1080/14330237.2013.10820625

Holmes, P.D.M., Chapman, T., \& Baghurts, T. (2013). Employee job embeddedness: Why people stay. International Journal of Business Management and Economic Research, 4(5), 802-813.

Holtom, B.C., \& Inderrieden, E.J. (2006). Integrating the unfolding model and job embeddedness model to better understand voluntary turnover. Journal of Managerial Issues, 18(4), 435-452. 
Janik, M., \& Rothmann, S. (2015). Meaningful work and secondary school teachers' intention to leave. South African Journal of Education, 35(2), 1-13. https://doi. org/10.15700/saje.v35n2a1008

Khawaldeh, K., Al Muala, A., \& Al Ziadat, M.T. (2014). Antecedents and mediators of turnover intention amoungst employees in private communication sector in Jordan: A structural equation modelling (SEM) approach Journal of Management and Sustainability, 4(3), 135-144. https://doi.org/10.5539/jms.v4n3p135

Ladebo, O.L. (2008). Perceived supervisory support and organisational citizenship behaviors: Is job satisfaction a mediator? South African Journal of Industrial Psychology, 38(3), 479-488. https://doi.org/10.1177/008124630803800303

Ladebo, O.J. (2009). Emotional exhaustion and strain reactions: Perceived organisational support as a mediator. South African Journal of Psychology, 39(1) 46-58. https://doi.org/10.1177/008124630903900104

Lavoie-Tremblay, M., Paquet, M., Duchesne, M., Santo, A., Gavrancic, A., Courcy, F., \& Gagnon, S. (2010). Retaining nurses and other hospital workers: An integrational perspective of the work climate. Journal of Nursing Scholarship, 42(4), 414-422. https://doi.org/10.1111/j.1547-5069.2010.01370.x

Luthans, F. (2005). Organisational behavior (10th ed.). New York, NY: McGraw and Hill.

Marques, L.A. (2013). Antecedents and outcomes of work-related psychological wellbeing of staff members of the University of Namibia. Unpublished Doctoral Dissertation. Windhoek: University of Namibia.

Medina, E. (2012). Job satisfaction and employee turnover intention: What does organizational culture have to do with it? Unpublished Master of Arts thesis. Columbia: Columbia University.

Mensele, C., \& Coetzee, M. (2014). Job embeddedness, organisational commitmen and voluntary turnover of academic staff at a higher education institution in South Africa. South African Journal of Labour Relations, 38(1), 9-30. https://doi. org/10.25159/2520-3223/5898

Meyer, J.P., Allen, N.J., \& Smith, C. (1993). Commitment to organisations and occupations: Extension and test of a three component model conceptualization. Journal of Applied Psychology, 87, 538-551. https://doi.org/10.1037/0021 9010.78.4.538

Mhlanga, D. (2021). The fourth industrial revolution and COVID-19 pandemic in South Africa: The opportunities and challenges of introducing blended learning in education. Journal of African Education, 2(2), 15-42. https://doi.org/10.31920/26332930/2021/v2n2a1

Mitchell, T.R., Holtom, B.C., Lee, T.W., Sablynski, C.J., \& Erez, M. (2001). Why people stay: Using job embeddedness to predict voluntary turnover. Academy of Management Journal, 44(6), 1102-1121. https://doi.org/10.2307/3069391

Mor Barak, M.E., Nissly, J.A., \& Levin, A. (2001). Antecedents to retention and turnover among child welfare, social worker, and other human service employees: What can we learn from past research? A review and metanalysis. Social Service Review, can we learn from past research? A review and $m$
$75(4), 625-661$. https://doi.org/10.1086/323166

Nunnally, J.C. (1978). Psychometric theory (2nd ed.). New York, NY: McGraw-Hill.

Perez, M. (2008). Turnover intent. Unpublished research thesis for Diploma in Business Administration thesis. Zurich: University of Zurich.

Pienaar, J., Siebehagen, C.F., \& Mostert, K. (2007). Investigating turnover intentions by role overload, job satisfaction and social support moderation. South African Journal of Industrial Psychology, 33(2), 62-67. https://doi.org/10.4102/sajip. v33i2.378

Pieters, W.R. (2015). Psychological empowerment and how it impacts on job satisfaction and organisational commitment of staff members at the University of
Namibia (UNAM). Namibia Journal of Managerial Sciences, 1(2), 98-120.

Pieters, W.R. (2018). The effect of job attitudes, job embeddedness and work engagement of turnover intention of academic staff at the University of Namibia. Unpublished Doctorate Dissertation. Bloemfontein: University of the Free State.

Ramlachan, K., \& Beharry-Ramraj, A. (2021). The impact of COVID-19 on employees, leadership competencies and human resource development. Gender and Behaviour, 19(1), 17219-17241.

Resi, H.T., \& Judd, C.M. (2000). Handbook of research methods in social and personality psychology. Cambridge: Cambridge University Press.

Robbins, S. (2003). Organisational behavior (10th ed.). Hoboken, NJ: Prentice Hall.
Rothmann, S., Barkhuizen, N., \& Tytherleigh, M.Y. (2008). Model of work-related ill health of academic staff in a South African higher education institution. South African Journal of Higher Education, 22(2), 404-422. https://doi.org/10.4314/ African Journal of
sajhe.v22i2.25794

Rothmann, S., Diedericks, E., \& Swart, J.P. (2013). Manager relations, psychological need satisfaction and intention to leave in the agricultural sector. South African Journal of Industrial Psychology, 39(2), 1-14. https://doi.org/10.4102/sajip. v39i2.1129

Rothmann, S., \& Jordaan, G.M.E. (2006). Job demands, job resources and work engagement of academic staff in South African higher education institutions. South African Journal of Industrial Psychology, 32(4), 87-96. https://doi. org/10.4102/sajip.v32i4.247

Russell, C.J., \& Van Sell, M. (2012). A closer look at decisions to quit. Organisational Behavior and Human Decision Processes, 117, 125-137. https://doi.org/10.1016/j. obhdp.2011.09.002

Ryan, S., \& Harden, G. (2014). Job embeddedness of information technology professionals: The effects of gender. Journal of Computer Information Systems, 54(4), 52-59. https://doi.org/10.1080/08874417.2014.11645722

Smit, W., Stanz, K., \& Bassin, M. (2015). Retention preferences and the relationship between total rewards, perceived organisational support and perceived supervisory support. South African Journal of Human Resource Management, 13(1), 1-13. https://doi.org/10.4102/sajhrm.v13i1.665

Snelgar, R.J., Renard, M., \& Venter, D. (2013). An empirical study of the reward preferences of South African employees. South African Journal of Human Resource Management, 11(1), 1-14. https://doi.org/10.4102/sajhrm.v11i1.351

Soltis, S.M., Agneessens, F., Sasovova, Z., \& Labianca, G. (2013). A social network perspective on Turnover intentions: The role of distributive justice and social support. Human Resource Management, 52(4), 561-584. https://doi org/10.1002/hrm.21542

Sousa-Poza, A., \& Henneberger, F. (2004). Analyzing job mobility with job turnover intentions: An international comparative study. Journal of Economic Issues, 38(1), 113-137. https://doi.org/10.1080/00213624.2004.11506667

SPSS. (2016). SPSS 24.0 for Windows. Chicago, IL: SPSS Incorporated.

Takawira, N. (2012). Job embeddedness, work engagement and turnover intention of staff in a higher education institution. Unpublished Master's Dissertation. Pretoria: University of South Africa.

Takawira, N., Coetzee, M., \& Schreuder, D. (2014). Job embeddedness, work engagement and turnover intention of staff in a higher education institution: An exploratory study. South African Journal of Human Resource Management, 12(1) 1-10. https://doi.org/10.4102/sajhrm.v12i1.524

Theron, M., Barkhuizen, N., \& Du Plessis, Y. (2014). Managing the academic talent void: Investigating factors in academic turnover and retention in South Africa. South African Journal of Industrial Psychology, 40, 1-14. https://doi.org/10.4102/ sajip.v40i1.1117

Van Dyk, J., Coetzee, M., \& Tebele, C. (2013). Organisational commitment and job embeddedness of service staff with critical and scarce skills. South African Journa of Labour Relations, 37(1), 61-78.

Van Schalkwyk, S., Du Toit, D.H., Bothma, A.S., \& Rothmann, S. (2010). Job insecurity, leadership empowerment behaviour, employee engagement and intention to leave in a petrochemical laboratory. South African Journal of Human Resource Management, 8(1), 1-7. https://doi.org/10.4102/sajhrm.v8i1.234

Wai, P.Y., Dandar, V., Radosevich, D.M., Brubaker, L., \& Kuo, P.C. (2014). Engagement, workplace satisfaction and retention of surgical specialists in academic medicine in the United States. Journal of American College of Surgeons, 219(1), 31-42. https://doi.org/10.1016/j.jamcollsurg.2014.03.027

Washeya, F.N., \& Furst, L.N. (2021). Work related factors that influence the retention of professional nurses in the public health sector in Windhoek, Namibia. Africa Journal of Nursing and Midwifery, 23(1), 1-17. https://doi.org/10.25159/2520$5293 / 8665$

Zhao, X., Sun, T., Cao, Q., Li, C., Duan, X., Fan, L., \& Liu, Y. (2012). The impact of work life on job embeddedness and affective commitment and their co-effect on org/10.1111/j.1365-2702.2012.04198.x 